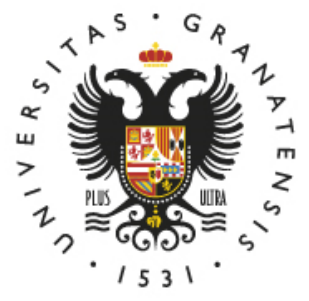

FACULTAD DE FILOSOFÍA Y LETRAS

DEPARTAMENTO DE FILOLOGÍAS INGLESA Y ALEMANA

MA Thesis by

Claire Marie Peeters

\title{
Stability and Greed: The Aesthetics of Gold in the Modernist Discourses of Ezra Pound and John Maynard Keynes
}

Supervised by Dr. José María Pérez Fernández

Master in English Literature and

Linguistics

Granada, January 2018 
Let us express our envy for the man with a steady job and no worry about the future.

You are very idle, my songs,

I fear you will come to a bad end.

—Ezra Pound, "Lustra” (1913)

Beware! The time for all this is not yet [...] Avarice and usury and precaution must be our gods for a little longer still. For only they can lead us out of the tunnel of economic necessity into daylight.

—John Maynard Keynes, "Economic Possibilities for Our Grandchildren” (1931) 
Yo, Claire Peeters, como autor de la memoria de este Trabajo Fin de Máster, asumo la originalidad del trabajo a excepción de las fuentes que han sido debidamente citadas. Para la elaboración del mismo, he participado activamente en todas las fases del trabajo, la interpretación de los resultados, la búsqueda bibliográfica y la redacción del manuscrito han sido trabajo mío, pero siempre supervisada por mí tutora.

En Granada, a 30 de Diciembre de 2017. 
Table of Contents

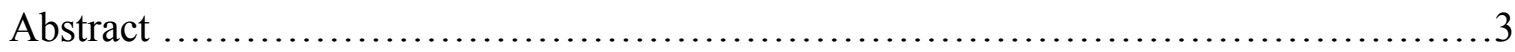

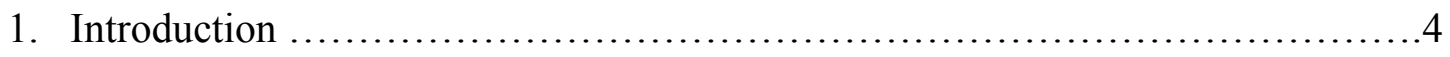

2. Theoretical Framework ............................................... 10

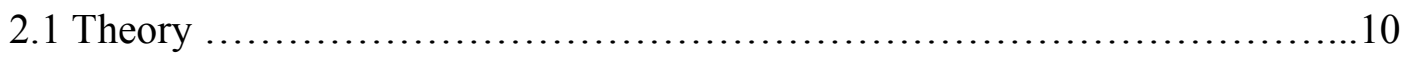

2.2 Instrument: Two Modernist Texts on Economics ........................18

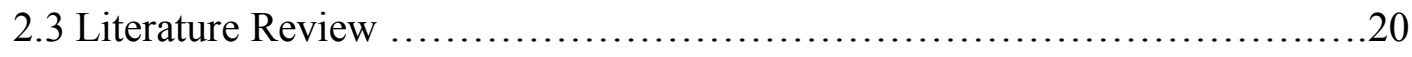

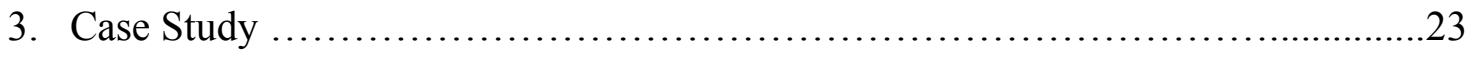

3.1 The Economics in Ezra Pound's Poetics .................................23

3.2 Stability and Greed: A Reading of "With Usura" .......................... 30

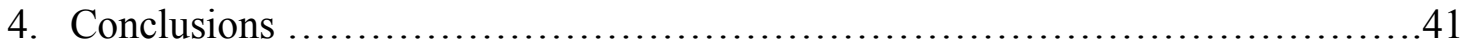

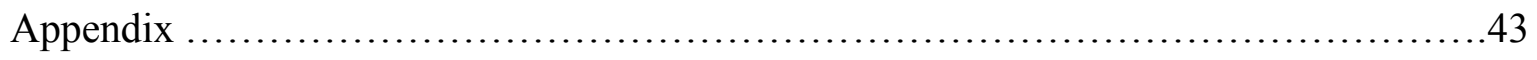

Canto XLV ......................................................44

Excerpt from A Tract on Monetary Reform ...............................46

Graph: Value of Gold in the Aftermath of the 2008 Financial Crisis ..............56

Portraits of J.M. Keynes and Ezra Pound ................................57

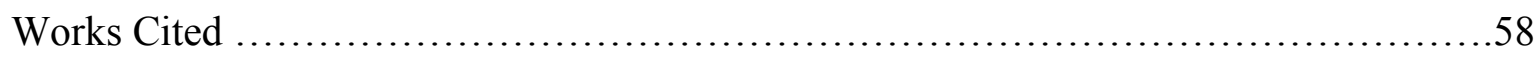




\begin{abstract}
Ezra Pound's poetry is infused with references to economic themes and ideas. One example is Canto XLV, "With Usura" (1936), which is underpinned by economic ideas. The discussion of Ezra Pound's poetics in this work, especially viewed against his economics, takes as its starting point discourses around gold and the gold standard. The gold standard was a widely contested policy issue in the first decades of the twentieth century. In this debate, we see the intersection of recurring themes that are evident in works of both poetics and economics, such as the importance of nature versus artificiality, the issue and problem of representation, and the pursuit of the "just" or the good. In this work, I apply a historically-informed close reading of Canto XLV, developing the aforementioned themes and contextualizing the poem using a textual comparative application of two modernist texts on economics. This work references as a comparative point of contrast the writings of the economist John Maynard Keynes (1883-1946), a giant in twentiethcentury intellectual and economic thought, who is seldom referenced in literary studies, but who was seen by Ezra Pound as the principal proponent, and in many ways the embodiment, of the capitalist society he so despised.
\end{abstract}




\section{Introduction}

Economics and literature are largely seen as belonging to different spheres of inquiry, with little formal overlap. There are nevertheless fruitful applications to studies of literature that highlight the importance of economic conditions in the formation of societal conditions or apply, with varying degrees of success, economic metaphors, such as the "poetics" of money, or the "currency" of language. Economics, a social science, sees itself, however, as divorced from the methods - and insights — of the humanities. In 1991, the Nobel Prize-winning economist and mathematician Gérard Debreu described the "mathematization of economic theory" as one of the "intellectual fashions" that had "in the past five decades $[. .$.$] became one of the prime movers in$ the transformation of [the field of economics]". He emphasized the importance of the "values imprinted on an economist by his study of mathematics" which "do not play a silent role" but rather "may play a decisive role", moving away from political economy, and questions of an ethical and philosophical nature (5-6). ${ }^{1}$

For their seeming discordance, economics and literature, especially poetics, are both fundamentally concerned with issues of representation and value. The highly abstract notion of “the economy" encompasses a network of myriad and never-ending interactions between economic agents_-individuals, firms, and governments — who produce and sell, buy and consume, exchange, and regulate. Economists must grapple with how to best model, on an aggregate scale, outcomes and predictions that stem from human whims and impulses, what can

\footnotetext{
${ }^{1}$ Marxism is a noteworthy example of an influential school—at least historically—of both economic and literary thought. Although Marxist criticism is still highly influential in literature, in contemporary economics Marxism is seen as a "fringe" view, relegated to the dusty back shelf of an elective graduate course in the history of economic thought.
} 
be coined, albeit problematically, "human nature". Economic theories often employ the tools and methods of mathematics to represent, in necessarily simplified terms, the interplay of economic variables. Expectations and perceptions are an essential part of economic theories, but they are often described in mathematical terms; mathematics is perceived to be a system of representation apart from poetics and language. But, even with mathematics, which has its own system of representation in numbers and symbols, we cannot escape "natural" language. ${ }^{2}$

Representation, as a topic of inquiry in itself, has figured more prominently in philosophy and literature. Since Plato and Aristotle, writers and literary theorists have directly grappled with language and how to best represent words, emotions, and concepts using a limited, and arbitrary, set of tools - namely letters and words. At certain historical moments, the question of representation seemed to be reaching a sense of resolution. At others, and reflecting the intake of broader anxieties, it became more acutely visible, especially in cultural outputs. This was, it can be argued, the case with works of modernism.

Modernism, particularly in literature, has been described as a profound crisis of "content and the form of representation" (P. Lewis xviii). Difficult to delineate and define, it was inseparable from social turmoil and key historical moments in the early twentieth century, notably economic upheaval, the First World War, and the troubled interwar period. We find in the literary, artistic, and philosophical works of modernism a theoretical and direct engagement with the immense anxiety and chaos produced by this change. Although the term modernism is generally used to describe "literature and the arts," it encompasses, as Lewis has argued, "a central phenomenon in cultural history" (P. Lewis xvii). Modernists were poets, writers, and

\footnotetext{
${ }^{2}$ Here we recall the words of Martin Heidegger: "We encounter language everywhere" ("Language" 984, emphasis mine).
} 
philosophers; the movements of modernism were diverse, but they had forms and tendencies in common. Analysis of these forms and tendencies can be extended to other disciplines, including science, politics, and economics.

The American poet Ezra Pound (1885-1972) and the English economist John Maynard Keynes (1883-1946) were two "moderns" who presented highly innovative theories of poetics and the economy, respectively, moving forward from Victorian and Enlightenment-era views of society and morality, individual human behavior, and rationality, while also engaging with works from the past. Both men were highly attuned to the polarized, and often explosive, issues of their day, although their political — and economic_-persuasions would lead them in vastly different directions. Pound was closely associated with anti-Semitism and Italian Fascism, a controversial stain on an otherwise remarkable poetic legacy; he is, as a 2007 review in The Economist pointed out, "as divisive a figure today as he was in his own lifetime" ("A Solitary Volcano"). Despite numerous attempts, Pound was never able to make his mark in economics, or to develop a coherent, original, or applicable economic theory. Today, he is remembered for his poetry, especially The Cantos, but not for his intellectual work in economics.

Keynes, however, was widely recognized as a brilliant and "distinguished economist, whose work for restoring the economic structure of a world twice shattered by war brought him world-wide influence," as a reverent 1946 obituary in the New York Times stated. He is today viewed as something of a heterodox and liberal savior of the Western capitalist system, although this view is reductive. Conversely to Pound, Keynes's writings outside of economics and political economy are largely forgotten. Best known today for his seminal 1936 work, The General Theory of Interest, Employment, and Money, arguably the single most important work of economics in the twentieth century, Keynes was also a member of the Bloomsbury circle and the 
Cambridge "Apostles" intellectual society, as well as a British policy maker and civil servant, professor at Cambridge University, and writer of countless books, articles, and letters. ${ }^{3} \mathrm{He}$ was also in close, and longstanding, contact with not only key political figures, but also important literary ones, such as Virginia Woolf and T.S. Eliot.

In the interdisciplinary case study that follows, I apply a historically-informed close reading of Pound's modernist poetry, contextualizing it using a textual comparative application of two complementary — and almost contemporary — texts by Pound and Keynes, respectively, which form my critical instrument. Pound was, like Keynes, a tremendously productive writer. His little-known 1933 text outlining his thoughts on economics, The A B C of Economics, is my first critical text, as it provides a rich source of insight into Pound's complex, and often confused, views on economic issues. My second critical text is Keynes's 1923 A Tract on Monetary Reform, specifically a section of the chapter "Alternative Aims," which focuses on the gold standard. I prefer to say "historically-informed" rather than use terms like "historicist," which are replete with meaning and immediately invoke other terms such as "new historicism." I applied the texts to a poem from The Cantos, "With Usura" (Canto XLV), published in 1936the same year as Keynes's General Theory. My reading of the poem is comprised of two parts. In the first, I provide background on Pound's poetics and economics, focusing especially on the issue of representation and the symbolism of gold, currents that traverse both facets of his work and thought. In the second, I turn more directly to the poem, drawing out the elements previously

\footnotetext{
${ }^{3}$ Other Apostles included Leonard Woolf, Lytton Strachey, and Rupert Brooke. The analytical philosopher G.E. Moore was also an Apostle, according to the Archives of King's College, Cambridge (“A Cambridge secret revealed: The Apostles”). Keynes's collected writings were published in 1978 by the British Royal Economic Society and take up an astonishing 30 volumes.
} 
discussed. This reading follows a brief theory section, and a summary of the historical context of the gold standard debate. Throughout the case study, the writings of Keynes are used as a comparative point of contrast.

In the analysis, I utilize discourses around gold and the gold standard, which feature in the economic writings of Keynes and Pound, and in the poetics of Pound. The gold standard, a now-abandoned system of monetary policy, bridges the gap between poetics, the philosophy of representation, and more "pragmatic" economic theories and policies. Gold is, and has been, from antiquity onwards, a remarkably powerful symbol, not only in literature, but also in politics and culture. In the gold standard debate of the early twentieth century, we unearth a modernist take on this symbolism, grounded in a topical issue that generated a wealth of textual evidence. This debate provides an excellent starting point not only for exploring discourses at the intersection of literature and economics - especially in macroeconomics, the study of the entire economy, which is so dependent on the aggregation of expectations and perceptions - but also for focalizing a discussion on Pound's convoluted economic thought, one fundamental lens through which to view his immensely complex poetics.

The perceived differences between Keynes, the Liberal English economist, and Pound, the populist American poet, are not as severe as they might initially seem. Their lives were, in certain ways, interwoven. They shared an interest in economics, and both men were opposed to a return to the gold standard, with Keynes famously referring to it in his A Tract on Monetary Reform as a "barbarous relic" (172), and Pound describing, in Canto LLIV, Churchill's 1925 return to the "putrid gold standard" (446). Both Keynes and Pound were extraordinary intellectual figures, radically innovative, and prolific in their output; they were both chronically misunderstood, not only during their lifetimes and by each other, but also today. They both 
sought to pursue their respective versions of a "just" society and had well-developed philosophical ideas and systems of thought that evolved over the course of their lives. Keynes, who was well-versed in aesthetics, art, and literature, produced economic theories that can also be described and analyzed aesthetically, yet he remains underappreciated outside of "mainstream" economics. ${ }^{4}$ He was also well-known to Pound, who personally despised Keynes and what he viewed as Keynes's “orthodox" tendencies.

An important motivation for this choice of subject was a longstanding personal interest in the figure of Keynes. In this thesis, I hope to have highlighted Keynes as a valuable critical counterpoint to the literary work of Ezra Pound, and, in the process, raised directions for future research. John Maynard Keynes is a foundational figure in twentieth-century intellectual history, who - in the tradition of the great early political economists who were his forebears, such as Adam Smith, John Stuart Mill, and David Hume, among many others — is of tremendous import to the study of literature. He also deserves to be widely read and studied within cultural studies and the humanities more broadly, beyond the rigid and deceptively mathematical confines of modern economics.

\footnotetext{
${ }^{4}$ A welcome exception is Richard Davenport-Hines's recent biography of “John Maynard Keynes without the economics," which argues "that Keynes deserves to be remembered for much else besides his economic works." This biography is, according to a review in the May 2015 issue of The Economist, something that would seem to most like a "'Hamlet' without the prince" ("A Man for All Seasons").
} 


\section{Theoretical Framework}

\subsection{Theory}

\section{(Golden) Signifier-Signified}

Today there is hardly consensus on the "question" of representation, which continues to be a source of active discussion — and contention — in literature, philosophy and linguistics. ${ }^{5} \mathrm{~A}$ full survey on this matter is beyond the scope of this paper. Certain theoretical approaches have, however, been especially influential, and are worth mentioning. Around the turn of the last century, the Swiss linguist Ferdinand de Saussure developed the terminological groundwork for subsequent work in linguistics and semiotics; his terminology continues to be used to the present day. Saussure's dualistic approach of "signifier-signified" was later deconstructed by the French semiologist Jacques Derrida and subsequent critics of the "Yale School" in the 1970s ("Paul de Man" 1361-4). One of these prominent critics, Paul de Man, in a 1973 essay, "Semiology and Rhetoric", elaborated on what is today arguably one of the most fundamental problems of representation, the problem of representation as "all". Citing the nineteenth-century American philosopher Charles Sanders Pierce, he said:

The interpretation of the sign is not, for [Charles Sanders] Pierce, a meaning but another sign; it is a reading, not a decodage, and this reading has, in its turn, to be interpreted into another sign, and so on ad infinitum. Pierce calls this process by means of which "one sign gives birth to another" pure rhetoric, as distinguished from pure grammar, which postulates the possibility of unproblematic, dyadic meaning and pure logic, which postulates the possibility of the universal truth of meanings. Only if the sign engendered meaning in the

\footnotetext{
${ }^{5}$ If anything, there is only consensus on the impossibility of consensus.
} 
same way that the object engenders the sign, that is, by representation, would there be no need to distinguish between grammar and rhetoric (29).

In the essay, de Man goes on to "try to illustrate the tension between grammar and rhetoric", ultimately arguing that literature and criticism are "condemned" to be "forever the most rigorous, and consequently, the most unreliable language in terms of which man names and modifies himself" (33). For this school of thought, and for many other contemporary philosophers and literary theorists, meaning and representation are infinitely generative and therefore ultimately unstable.

Against this influential deconstructionist view, gold as a signifier provides an interesting case. ${ }^{6}$ In cultural, monetary, and even transcendental terms, gold has immense—and nearuniversal—symbolic power. As a signifier, it has a firm basis of value: It is a precious metal, ascribed with indisputable worth, no matter how worth is defined. Perhaps deceptively, it is unlike a verbal or written sign; with gold, sign and object are one. Gold therefore has the potential to terminate the infinite cycle of endlessly perpetuating, and perpetuated, signifiers. As a monetary store of value, gold, with its near-mythical import, created its own set of problems at various moments in history, when "true" (monetary) value and "perceived" (symbolic) value failed to unite. Elvira Vilches, in her book New World Gold: Cultural Anxiety and Monetary Disorder in Early Modern Spain, discusses one instance, in early modern Spain. She explains the tension that arose from the fact that "Spanish culture" at this time period had remained "attached to gold as a substance of intrinsic value", which became problematic when the "wonder" at

\footnotetext{
${ }^{6}$ Recognizing that the aforementioned theories were developed in relation to language and linguistic signs. Arguably, the logic can be extended to other signs, which are no more or less arbitrary than linguistic ones. The issue of whether a sign is tangible or not is a different matter altogether.
} 
seeing the treasures brought back from the Indies turned to "confusion and distress, as goldsupposedly an object of everlasting value — began to fluctuate [in value]" (3-4). The problem of representation is, as has been mentioned before, a central concern in both economics and philology. A peculiar case arises when economics and symbolism meet, when one measure of value (or meaning) becomes unmoored from others.

\section{The New and the Gold: Historical Context of the Gold Standard Debate}

The gold standard debate of the early twentieth century provides a more recent example of an instance when the symbolic value accorded to gold played with—and contradictedeconomic forces. This interaction had a discernable impact on the economies of the United States and Great Britain. The gold standard was a monetary system whereby "the prices of $[\ldots]$ domestic currencies" were fixed in "terms of a specified amount of gold" (Bordo 1). This system contrasts with our now-familiar modern system of fiat money, which allows credible central banks to control the money supply and set monetary policy. ${ }^{7}$ Theoretically, a rigid gold standard - based on the direct relationship between the value of a paper currency and a physical amount of gold—would lead to price stability. ${ }^{8}$ As Keynes explained in A Tract on Monetary

\footnotetext{
${ }^{7}$ According to the Financial Times' lexicon of economic terms, a central bank is: the "monetary and major regulatory bank in a country. Its functions include issuing and managing the country's currency, controlling monetary policy and supervising money market operations, managing exchange and gold reserves, acting as lender of last resort to commercial banks, and providing banking services to the government" (2017).

${ }^{8}$ Price stability is a macroeconomic concept. According to the European Central Bank's site (2017), it refers to the state when aggregate prices are stable; in other words, there is no sustained inflation or deflation. A rapid increase in inflation can lead to economic hardship and a rise in inequality.
} 
Reform, the gold standard did, for a number of structural reasons, "work" in the nineteenth century. As a system of monetary policy, however, a gold standard is "no guarantee of price stability" according to the macroeconomist David Andolfatto, a Vice President of the St. Louis Federal Reserve (2014). Both the United States and Great Britain had gold standard regimes throughout most of the nineteenth century, which were suspended during World War I to give governments more fiscal flexibility as they tried to fund their war efforts. England sought to prematurely reinstate the gold standard in 1925, a move that was publicly denounced by Keynes and one that would ultimately be accepted as a "mistake" (Skidelsky 263). ${ }^{9}$

The United States, too, faced the detrimental effects of policymakers' adherence to a gold standard, which significantly inhabited the recovery following the Great Depression in the 1930s, the single most devastating economic event in the history of the U.S. In their study of the Great Depression, the economic historians Barry Eichengreen and Peter Temin argue that the "most important barrier to actions that would have arrested or reversed the decline [of the depression] was the mentality of the gold standard." They claim that this mentality "and the institutions it supported limited the ability of governments and central banks to respond to adversity" and furthermore "led to the adoption of policies that made economic conditions worse instead of

\footnotetext{
${ }^{9}$ For a complete timeline of the gold standard in the nineteenth and twentieth centuries, see www.uk.reuters.com/article/idINIndia-52748720101108. David A. Moss also provides a concise history, specifically of policy in the United States, in the fourth chapter ("A Short History of Money and Monetary Policy in the United States") of his A Concise Guide to Macroeconomics (2007).
} 
better" (1). Both England and the United States would soon be forced to permanently abandon a rigid gold standard in favor of more flexible regimes. ${ }^{10}$

In a 2016 interview, the American economist Dean Baker, of the Center for Economic and Policy Research, stated there are very few economists and economic historians today, "who can look back at the history and why countries moved away from the gold standard who would say, that was a mistake, and somehow we need to get back to that." The idea, however, of a "return" to the gold standard has never fully gone away, however ill-advised such a policy might be in practice. Also in 2016, then-presidential candidate Donald Trump spoke in glowing terms of a gold standard, saying, "Bringing back the gold standard would be very hard to do, but boy, would it be wonderful. We'd have a standard on which to base our money." 11

Trump's comments, and the fact that the gold standard is periodically re-introduced as a sort of panacea to economic woes - even if it has been thoroughly disproven as a tried economic policy_points to the fact that there is something inherently comforting about having currencies (theoretically) "backed by gold reserves and exchange rates [...] fixed in terms of their value to gold". ${ }^{12}$ Gold maintains its allure — and its tangible value — and the word standard separately has connotations of order and stability; the two words together suggest that it would be possible to

\footnotetext{
${ }^{10}$ The new international monetary order established at the 1944 Bretton Woods conference after the second World War, where John Maynard Keynes also served as an advisor, would be based on some of these same principles. A "modified gold standard was restored after World War II" but it "eventually fell out of favor as well and was dropped for good in the early 1970s" (Moss 93).

${ }^{11}$ Both quotes are from a 2016 National Public Radio emission ("Trump Favors Returning to The Gold Standard, Few Economists Agree").

${ }^{12}$ According to the Financial Times' lexicon of economic and financial terms (2017).
} 
manage and stabilize vexingly fickle macroeconomic forces, particularly inflation and exchange rates. ${ }^{13}$ Gold's "marginal value" was described by Keynes in $A$ Tract on Monetary Reform (referring specifically to the gold standard) as being "governed by a steady psychological estimation of the metal in relation to other things. This is what is meant by saying that gold has 'intrinsic value' and is free from the dangers of a 'managed' currency" (Keynes 166). Gold is also a "safe haven" commodity for investors, and its price, reflecting increased demand, goes up during times of political uncertainty and economic crisis. ${ }^{14}$ It is seen as a store of monetary value that enjoys a certain level of immunity from volatile market forces that cause other investments to fluctuate more severely in price.

Andolfatto, from the St. Louis Fed (2014), explained how President Franklin D. Roosevelt and the U.S. Congress were able to manipulate the value of gold in the 1930s by essentially modifying the "official" value assigned to units of gold, thereby distorting the mechanism of the gold standard. Along with other measures, it was a way to change the money supply, and the level of inflation (the aggregate price level) in the United States. The gold standard can, therefore, be "a promise made 'out of thin air' to keep the supply of money anchored to the supply of gold." 15 In this case, gold, and the gold standard upon which it was

\footnotetext{
13 "Inflation is a general increase in prices [...] Unless matched by an increase in wages, inflation means a loss of purchasing power for the consumer. It also reduces the value of a country's currency, as more units of currency are needed over time to buy the same goods." An exchange rate is "the rate at which one currency can be exchanged for another." Both definitions are from the Financial Times' lexicon (2017). ${ }^{14}$ A graph, which is included in the appendix on page 56, shows how the value of gold steadily increased in the aftermath of the 2008 global financial crisis, peaking in 2011.

${ }^{15}$ In the same way that the Federal Reserve can today "print" money "out of thin air".
} 
based, became a deceptive and artificial symbol. In 1923, Keynes wrote about how the United States had, a few years earlier, been able to warp the "natural" value of gold:

The United States has not been able to let gold fall to its "natural" value, because it could not face the resulting deprecation of its standard. It has been driven, therefore, to the costly policy of burying in the vaults of Washington what the miners of the Rand have laboriously brought to the surface. Consequently gold now stands at an "artificial" value, the future course of which almost entirely depends on the policy of the Federal Reserve Board of the United States. The value of gold is no longer the resultant of the chance gifts of Nature and the judgment of numerous authorities and individuals acting independently $(167) \cdot{ }^{16}$

The reference to "natural value" is highly significant, and the concept of "Nature"-from which gold, a precious metal, is issued — carries weight in macroeconomic theory, poetic theory, and theories of political economy and society. Often, the natural and the good are interchangeable; nature is considered a transcendental standard, foundational for "true" poetry as well as "true" and good societies. The notions of the organic, the natural, and the wholeverging on a sort of natural organicism — are apparent in both the poetics and the economics of Ezra Pound. Pound was highly critical, by moments paradoxically and simplistically so, of the capitalist society that was nevertheless also dependent on the outputs of "Nature" to maintain economic stability. As the quote above illustrates, Keynes believed that the conditions for gold to have maintained its "natural" value no longer existed at that particular moment in history, and it therefore needed to become "managed". This move towards "artificiality" in monetary policy was exactly the sort of thing that Pound, hardly the pragmatist, opposed. He believed that gold

\footnotetext{
16 "The Rand" refers to gold mines in South Africa.
} 
had become just another form of money, which moved away from his idealized "organic" economic system directly based on "natural" or "true" value. 


\subsection{Instrument: Two Modernist Texts on Economics}

Two texts formed the instrument for my critical reading of Ezra Pound's Canto XLV. Written a decade apart, in 1923 and 1933, respectively, they are both texts of economics. They are briefly introduced below.

John Maynard Keynes's A Tract on Monetary Reform (1923)

Keynes's A Tract on Monetary Reform was published by Macmillan and Co. on December 11, 1923. According to Skidelsky, it summarizes, in 209 pages, "what Keynes had been thinking and writing about the theory, practice and objects of monetary policy". The primary argument of the Tract was that monetary policy should "be used to stabilize the price level, rather than the supply of money" (Skidelsky 329). I will only be concerned with the third part of Chapter IV, "Alternative Aims," which is titled "The Restoration of a Gold Standard". ${ }^{17}$ In this chapter, Keynes, in characteristically ironic and unequivocal terms, attacked the gold standard (Skidelsky 330). He argued that it had been effective at maintaining price stability in the nineteenth century, but this was "owing to 'special conditions' which had disappeared" by the 1920s (Skidelsky 332). This excerpt is especially helpful insofar as it helps disentangle the economic concept of gold as a "managed" and "artificial" currency within the very liberal economic system that Pound would view as distorted, and far from his ideal society resembling an "organic" whole and based on direct exchange and a clear mapping between production and value.

Ezra Pound's A B C of Economics (1933)

Published by Faber and Faber in 1933, a decade after Keynes's A Tract on Monetary Reform, the $A B C$ of Economics is a slim volume of 128 pages. It was based on "ten lectures"

\footnotetext{
${ }^{17}$ The excerpt can be found in the appendix on page 46 .
} 
Pound had delivered in "an Italian university" and sought to "express the fundamentals of economics so simply and clearly that even people of different economic schools and factions will be able to understand each other when they discuss them" (7). The text is introduced on the original dust cover in a "blurb" that was, as Redman has argued (95), most likely written by Pound himself, as a series of lectures "Mr. Ezra Pound was asked to deliver [...] not on the mummified muses" but rather as a "necessary evisceration and clarification [...] a concise introduction to "volitionist economics." Organized into three parts, this $A B C$, significantly less known than Pound's classic in literary criticism, the $A B C$ of Reading (1934), is written in short chapters. It touches on several subjects, including “Inflation and Deflation,” Malthus, Major Douglas, free trade, and the nature of economics. Economics is defined as the discipline "concerned with determining WHAT financial measures, what methods or regulation of trade, etc., must be taken, or can advantageously be taken or decreed by government $[\ldots]$ or by whatever elected or haphazard or private or dictatorial bodies or individuals control trade, credit, money, etc." (A B C of Economics 63). ${ }^{18}$ The $A B C$ of Economics is by moments whimsical, by others philosophical; it is free of excessive terminology and technical rigor, but its economic logic is difficult to follow. In what could be interpreted as a small nod to his meeting weeks before with Benito Mussolini on January 30, 1933, Pound signed the text, "E.P. Feb. 12, anno XI dell' era Fascista" (Redman 95). This text helps to formally situate and articulate Pound's economic thinking.

\footnotetext{
${ }^{18}$ Thomas Malthus, the nineteenth-century political economist who is especially known for his views on population growth. Inflation is defined on page 15. Major Douglas refers to Major C.H. Douglas.
} 


\subsection{Literature Review}

Dealing with Pound or Keynes, separately, presents its own challenges. Ezra Pound's writings can be dense and esoteric, complex, and with a startling breadth of references. Scholars are also faced with a peculiar conundrum when trying to decide how to approach his political sins, namely his Fascism and anti-Semitism; "for many [readers] the perception of Pound as a crazed, right-wing bigot blocks any desire to approach the poetry" (Redman 1). Keynes, for his part, is seldom treated in any great depth in the context of literary criticism. A full treatment of why Keynes has been largely "ignored" within cultural studies is not possible in the context of this thesis. It would require tracing the history of macroeconomic thought, in the context of intellectual history, in both the nineteenth and twentieth centuries.

Pound himself did not properly understand Keynes's intentions and work, and he had personal biases that affected his judgement towards Keynes, as I explain in more depth in Section 3.2 below. Just as Pound was "that rare things among modern poets, a scholar,"19 Keynes was also an anomaly, whose interests drifted through philosophy, mathematics, politics, and economics. Because, however, some of his writings err to the technical side and contain equations and mathematical reasoning, they can be difficult or intimidating for non-economists, despite the rare lucidity of his prose. This is, perhaps, not only a reason Pound misunderstood Keynes, but also a contributing factor as to why it remains somewhat unusual for elements of Keynes's thought or life to be treated in any sort of depth, outside the context of economics.

The way subsequent economists—-but also scholars in disciplines in the humanitieshave treated Keynes does a disservice to the scope and innovation of his thought. Keynes's most important work, the sweeping and elegant General Theory, is treated, with few exceptions, and

\footnotetext{
${ }^{19}$ Via an early review (“Ezra Pound” 2017).
} 
like most of Keynes's writings, as a work exclusively of economics. There is, however, an important case to be need for its being a significant work in the modernist canon. Macroeconomic theory and monetary policy have an aesthetic, a mode and form of representation. While the General Theory is topically concerned with economic matters, it also provides an alternative mode of and structure for interpretation. Its conceptualization of the economy uses aesthetic terms and language that is often rich in allusion and metaphor, a theoretical framework that could be applied to the study of literary texts. The application of Keynesian thought to literature, as a well-defined theoretical system, in the same way as currents of Marxist thought have been so successfully applied to the study of literary and cultural works, would likely yield rich and novel insights.

\section{Previous Work that Deals with Ezra Pound's Economic Thought}

In Ezra Pound and Italian Fascism (1991), Tim Redman provides a thorough treatment of Pound's economics, tracing the evolution of his thought in detail, including his relationship with Major Douglas and Social Credit, his optimistic view of Mussolini, and the politicizing of his poetry. Other relevant work includes the essay by Ricard Sieburth, "In Pound We Trust" (1987), which comprehensively examines the symbolic importance of gold, and its evolution, in the poetics of Pound; Paul Morrison's Poetics of Fascism (1996), which contemplates Pound's work against his politics, and from a more theoretical perspective; and a well-cited study by Jean-Michel Rabaté, Language, Sexuality, and Ideology in Ezra Pound's Cantos (1986), Chapter 5 of which ("Poundwise: Towards a General Critique of Economy, 183) touches on usury, the economics of culture, and some of the larger cultural references in The Cantos. Although Pound's economics have been examined in detail, Keynes-with whom Pound was so 
preoccupied — is in the literature on Ezra Pound's economics treated overwhelmingly as a peripheral reference.

There is other intriguing work that attempts to bridge the gap between literature and Keynes more generally, focusing for example on the Bloomsbury connection. Previous work on the overlapping motifs in the works of Virginia Woolf and John Maynard Keynes has been limited, but intriguing. Jennifer Wicke wrote a somewhat influential essay in 1994, titled “"Mrs. Dalloway' Goes to Market: Woolf, Keynes, and Modern Markets" in which she draws parallels, arguably too broad, between impulses in Keynes's General Theory of Interest, Employment, and Money and Virginia Woolf's Mrs. Dalloway. In a post for the Yale Modernism Lab Wiki, Merve Emre offers a thoughtful critique of Wicke's paper, presenting a more exhaustive—and nuanced - explication of Keynes's economic theories; she also examines relevant passages from Mrs. Dalloway, focusing on the importance of "convention." 


\section{Case Study: Ezra Pound's "With Usura" (Canto XLV)}

The Cantos is one long poem, or over 100 individual ones, depending on how the individual poems are counted. They were written over several decades. A remarkable project, it is Pound's best-known work and a stunning achievement in the canon of not only twentiethcentury literature, but poetics more broadly. In this section, I will analyze the poem "With Usura" (Canto XLV), which was published in 1936. The poem in its entirety can be found in the appendix, on page 44. Although aesthetically "With Usura" is not Pound's most elegant work, it is useful for a discussion on representation and natural value, particularly as it relates to the poet's views on economics and poetics more generally. Before delving into the poem, I will first explain salient elements related to these views in greater depth.

\subsection{The Economics in Ezra Pound's Poetics}

\section{Representation and Gold: Mediation in Pound's Poetics and Economics}

In his poetics as well as his economics, Pound sought to remove artificiality and artifice, to avert the generative anxiety of representation that was recognized and, in some cases, openly embraced and subverted by other modernists. ${ }^{20}$ Like the proponents of the gold standard who wanted the value of currencies to map directly to the value of a fixed amount of gold, Pound wanted to establish a direct relationship between word and meaning. The "direct treatment of the 'thing"” was the aspiration of his earlier Imagism (Lewis 83). While some of his contemporaries rejected the possibility of mimesis, the "victory of free verse over traditional meters, decisively won in English by Ezra Pound and his friends, was actually undertaken in the name of mimesis. Pound emphasized that poetry should imitate spoken language rather than conventional meters"

\footnotetext{
${ }^{20}$ Here we think of the avant-garde movement, especially of Dada in art.
} 
(Lewis 5). He also emphasized the importance of using "language and rhythms of speech" in poetry, "rather than artificial poetic conventions" (Lewis 118).

Pound had a second aim in his work, one that was arguably at odds with the first. He strove to achieve a certain timelessness - one could say reaching towards a transcendental quality—in his poetics, emulating works he saw as classics. Long modernist poems including The Cantos looked "to the deep-lying structures of ancient mythologies and prehistories for paradigms of formal and conceptual order." ("Modernism" 892). Pound defined "classics" in the $A B C$ of Reading as those works "having a certain eternal and irrepressible freshness" (11-12). Much of his poetry "takes the form of translation, imitation, allusion, and quotation" and he tried "to breathe life into a line of artistic and intellectual accomplishment, but it is a line of his own invention" (Menand 2008). ${ }^{21}$ A great work needed, for Pound, to remain new and retain this "freshness" even as its temporal and historical context changed. As he stated in the $A B C$ of Reading: "There is one quality which unites all great and perdurable writers, you don't NEED schools and colleges to keep "em alive" (45). This is, as with other elements that flirt with transcendentalism, a highly convenient solution to the fundamental problem of representation. "Great" works are obviously great. You don't need "schools" to study them and keep them in the canon of great works. Their greatness is, to the reader, simply evident. The problem, of course, is that meaning, and with it the "irrepressible freshness" Pound sought, also breaks down in time. In much the same way, the gold standard, which had been quite successful at maintaining price stability in the nineteenth century, broke down, according to Keynes, after the First World War. Before the war, the "convention" of the gold standard had been successful. "The War broke down the convention; for the withdrawal of gold from actual circulation destroyed one of the

${ }^{21}$ For more on the paradoxical dimensions of Pound's treatment of translation, see Morrison 1-2. 
elements of reality lying behind the convention, and the suspension of convertibility destroyed the other" (Keynes 171-2). Keynes stated that advocates of the gold standard (after the war) based "their cause on the double contention, that in practice gold has provided and will provide a reasonably stable standard of value". Critically, "superstition" was also a factor. Keynes recognized the symbolic weight of gold. Gold, the eternal and transcendent symbol, deceptively enjoyed "the prestige of its smell and colour" (164).

The word "gold" is explicitly mentioned only once in "With Usura" ("None learneth to weave gold in her pattern"), but it is used as an extremely familiar conceit, denoting pure value. More broadly, The Cantos are infused with the imagery of gold, as Sieburth has demonstrated (1987). Economic references are often intertwined with, and in certain cases inseparable from, references to gold. Gold is, however, a complex and paradoxical symbol; it is not stable throughout The Cantos. In Pound's early poems, gold is a "floating signifier of both poetry and desire" (145). In the earlier Cantos, gold is "metonym of the transcendent fire of the sun, that most powerfully figures the pure ideality of divine or poetic vision in these initial Cantoswhether it be Circe in her 'golden girdles,' 'bearing the golden bough of Argicida' (1:5), Danac awaiting 'the golden rain' (4:16), or the work of the artist 'weaving with points of gold' (5:17)" (151). According to Rabaté and Sieburth, it is not until Canto XXVI that gold begins "to acquire unmistakably malevolent connotations" (Sieburth 151). There is a parallel to be drawn between the "corruption" of gold's symbolic "purity" in these later poems and the problem of what Sieburth calls "mediation" that appeared (concordantly, it can be argued) with increasing prominence in Pound's economic thought (152) - this mediation, of which gold (or other types of "money") was the tangible vehicle, was a distortion of natural value. Pound favored "direct 
barter" in economic exchange, and much of his "monetary theory can be understood as an attempt to eliminate or severely regulate this third substance (money or gold)" (151).

Just as Pound's Imagism had been a "fundamental attempt to get his poetry off the gold standard, to defetishize the signifier, as it were, to establish a poetics whose economy would be based on the direct exchange between subject and object" (Sieburth 146), the emphasis on "direct exchange" was present in his economics. At a literal level, he strongly criticized economists for not using clear language, and for using one sign (word) to signify several economic concepts. In a 1934 questionnaire Pound sent to friends, one of the statements he posed (under the heading, "WHICH of the following statements do you agree with?") was, "Some of the commonest failures of clarity among economists are due to using one word to signify two or more different concepts: Such as DEMAND, meaning sometimes WANT and sometimes power to buy; authoritative, meaning also responsible". ${ }^{22}$ Pound wrote his $A B C$ of Economics presumably in part to respond to this problem of terminological clarity in economics; in it, he rails against what he sees as deliberate obscuration on the part of economists. ${ }^{23} \mathrm{He}$ states that "the 'science' or study of economics is intended to make sure no one" answers the simple question, "Why should anyone starve?" (13). ${ }^{24}$

22 "Volitionist Economics" (144).

23 "When I express a belief I will say so" ( $A$ B C of Economics 13).

${ }^{24}$ This question also points to one of the central economic "questions" that Pound wanted to answer, related to that of "under-consumption". "Probably the only economic problem needing emergency solution in our time is the problem of distribution. There are enough goods, there is superabundant capacity to produce goods in superabundance" (16-7). 


\section{The "Perfect Economic State": Social Credit and Natural Wealth}

Pound was an enthusiast proponent of Major C.H. Douglas' theory of "Social Credit", upon which his own economic views and theory of a "perfect economic state" were very directly based. ${ }^{25}$ Douglas, an English engineer, wrestled with the problem of under-consumption, one of the issues that preoccupied economic thinkers of the time. Douglas was known to Keynes; furthermore, he was attacking the "two fundamental laws of the orthodox economics of his day", which Keynes "did later" (Redman 63). ${ }^{26}$ Social Credit was based on a "national dividend" that would, theoretically, "keep purchasing power equal to the goods and services being marketed" (Terrell 180). By transferring power from bankers to the state, the "basis of credit would be the productive potential of the nation, not access to gold" (Marsh 118). Douglas had started writing for the New Age, the literary magazine to which Pound also contributed, in 1919 (Redman 45). Furthermore, Pound's investigation into the "causes of war" - an important motivation for his

${ }^{25}$ C.H. Douglas is "the major" in Canto "XLVI" (Terrell 180).

${ }^{26}$ In the General Theory, Major Douglas is mentioned twice. The first time, it is somewhat disparagingly, when Keynes notes that mainstream economists have failed to address the "great puzzle of effective demand," which could therefore "only live on furtively, below the surface, in the underworlds of Karl Marx, Silvio Gesell or Major Douglas" (29). Later in the book, he critiques Social Credit in more detail, the "most famous" in a "spate of heretical theories of under-consumption". Keynes recognizes that "the strength of Major Douglas's advocacy has, of course, largely depended on orthodoxy having no valid reply to much of his destructive criticism. On the other hand, the detail of his diagnosis [...] includes much mere mystification" (230). 
very foray into economics - was "sparked by his meeting with Major C.H. Douglas in 1918" (Redman 51).

The fair and, critically, just distribution of "credit slips" was the means through which the hypothetical dividend in the Social Credit system would be distributed. "I take it that in the perfect economic state the cost of the money is reduced almost to nothing, to something like the mere cost of postage, and that this cost is borne by the state, i.e. distributed so as to be a burden on no one in particular" ( $A$ B C of Economics 92). Pound wanted, idealistically, the number of "printed certificates of value" to increase in direct correlation with the (natural) generation of wealth in a nation's economy: "As certificate of an increasing productivity, increase of product, increase of means of production there SHOULD be an increase in the printed certificates of value" (114). Furthermore, there was a moral component to the system. These increases in value needed to be set by people whose "motivation should be the bonum publicum, the commonweal and not the shifting and shaking the sieve for the benefit of a few highly-placed crooks, scoundrels and exploiters" (117). A key problem Pound saw with the gold standard, a "fetishization of the sign", was that it had "no 'organic' relation to the rhythms of "natural increase", and could therefore "only misrepresent the reality of wealth, which is derived from nature alone" (Morrison 53). Pound recognized gold as another signifier subject to manipulation - and exploitation.

Pound's "honest certificates of work done" (27) were essentially (theoretical) stable signifiers of value. "The certificate of work done must equal that work" (39). Instability of representation, which led to money having an artificial "cost", was not only misleading, it was tied to injustice. In his more ideal society, labor would be rewarded at a fixed rate; the value of 
work would therefore be stable and "fair". 27 "When the certificate is not 'money' or common carrier, but a particularized certificate, it is 'just' in the sense that the order to deliver so many bushels already 'paid for' implies so many bushels. A certificate made out in 'common carrier' will not automatically stabilize currency or produce justice, unless some common sense is used in the production of goods" (40). Usury or rents — and injustice — could result when money had a "cost" beyond its value, just as artifice added something unnecessary to poetic language.

${ }^{27}$ For more on Pound's vision of a Utopic society, see footnote 26 in Sieburth (153). 
3.2 Stability and Greed: A Reading of "With Usura"

Pound used the word "usury," one of the recurring motifs in his work, for the first time in a poem in 1910 (Sieburth 144). According to the Concordance compiled by Dilligan et al., "usury" and related words appear sixty-six times throughout the The Cantos. A full breakdown is below:

USURER'S: 1

USURA: 33

USURER: 1

USURERS: 3

USURERS': 2

USURIES: 3

USURIOUS: 2

USURY: 18

66

In Canto XLV, Pound portrays a small society. This previously organic and wellfunctioning society has been corrupted by usury, an unseen force that is literally "CONTRA NATURAM"- against nature. ${ }^{28}$ There is a direct connection here to artificiality; an economic society corrupted by a force against nature is open to exploitation and suffering. With usura, a "sin against nature," "the line grows thick / with usura is no clear demarcation". The reference to "sin" brings the idea of justice into the poem. In this society, pictures are cheap and "made to sell

\footnotetext{
${ }^{28}$ The phrase "contra naturam", according to Merriam-Webster, means "against nature: not in accordance with the natural order or with religiously sanctioned normality". It is compared to the phrase "secundum naturam", which is the Latin for "according to nature" (2017).
} 
and sell quickly" (12), evoking the lure of a capitalist market, motivated by profit. Pound, according to Morrison, saw usury as the "blockage or mediation" that occurs when wealth is misrepresented (similarly to the unnecessary mediation through money, including gold); this is compared to "a just or true representation of wealth participates in the nature of the reality it renders intelligible" (54). In a similar manner, azure and emerald—semi-precious and precious gemstones, respectively - are disconnected in the poem from both their "value" and that which they represent. Azure "hath a canker" and "Emerald findeth no Memling". ${ }^{29}$ Corpses, normally associated with death and decay, are "set to banquet" at the "behest" of usura. Usura "slayeth the child in the womb / It stayeth the young man's courting”. Even the mythical body of Eleusis is corrupted; "They have brought whores for Eleusis."

The simplified economy portrayed in the poem is based on "natural" and direct exchange, with little to no mediation between buyer and seller; however, these exchanges, and the very modes of production, are corrupted by "usura." Usura is directly tied to the institutions of banking, which Social Credit would happily have disposed of, in the reference at the end of the poem to the "failure" of the Medici bank. Pound uses the example of sheep in the $A B C$ of Economics ("WITH USURA / wool comes not to market / sheep bringeth no gain with usura") to illustrate his idealized mode of "natural" wealth generation: "Crises in the sheik and sheep trade seldom occur. I mean that the primitive grazer counts his sheep and is not continually worried if

\footnotetext{
${ }^{29}$ Hans Memling was a fifteenth-century Flemish painter. In this reference, we see that Pound is playing with representation on multiple levels, saying that with usura, not only do literally "natural" (i.e. emanating from the natural world) signs like gemstones lose their direct power of representation, they are themselves no longer the subject of other traditional mediums of representation, such as the visual arts, here specifically painting.
} 
he cannot sell out his whole herd [...] The shepherd's sheep multiply, the crops that are sown multiply, and neither requires much work" (95). Wealth generated "naturally," such as through the propagation of sheep and crops, is, however, valid and not "artificial".

Stability, Fascism, and the War: The Political Economy of "With Usura"

Although "With Usura" seems to be set in an earlier epoch, with its imagery of a pastoral society and use of archaic verb tenses ("hath", "receiveth") and determiners ("thy"), the poem has a very contemporary interpretation. The Cantos aspired to be an "epic," which Pound defined as a "poem including history" ( $A B C$ of Reading 46). But history is not just something in the past. Multiple poems in The Cantos, including "With Usura", have very clear references to contemporary events—current history—alongside references to older historical events or periods. Pound saw usury as a destabilizing force stemming from greed. Usury needed to be neutralized, even if it came at the expense of individual freedom. A dictator-such as Mussolini—could be seen as a stabilizing (and idealized) symbol, in which signifier and signified unite. Tyranny, for Pound, was a lesser evil than the effects on society of a political and economic system that allowed greed and usury to thrive. Keynes is again a useful counterpoint here, as he was not only Pound's ideological foil, but had a similar starting point—and therefore set of motivations, at least on some level.

Like so many others of their generation, John Maynard Keynes and Ezra Pound had been swept up by the irrevocable disillusionment brought by the First World War and its aftermath in Europe and beyond. Their reactions to this event, together with their respective persuasions on economic theory, are crucial to understanding not only major divergences in their thinking on 
economic and social matters, but the very arc of their subsequent work. ${ }^{30}$ After 1919 , the sense that the world had changed was definitive. This certitude, however, had come on the back of a devastating event, one in which millions of people had died. On 8 July 1919, Virginia Woolf wrote in her diary about Keynes, "He is disillusioned, he says. No more does he believe, that is, in the stability of the things he likes. Eton is doomed; the governing classes, perhaps Cambridge too." (Skidelsky 233-234). ${ }^{31}$ Although Keynes was in many ways iconoclastic, he was also well entrenched in Cambridge intellectual and social circles. After the war, even these vulnerable and established bastions of "stability" could no longer be counted on.

Pound also tried to rationalize the war, but he framed it in terms of greed, most especially usury, which he defines in a small prologue at the end of "With Usura" ("N.B. Usury: A charge for the use of purchasing power, levied without regard to production; often without regard to the possibilities of production. [Hence the failure of the Medici bank.])" The gold standard had played its part. For him, the gold standard had played into the hands of the "gang of bankers" to which England had succumbed ( $A$ B C of Economics 64$)$. The First World War was the "mechanism by which the 'usurocracy' brought about an expansion of purchasing-power and the creation of debts during a period when money was plentiful." Then, Churchill's "return to gold"

\footnotetext{
${ }^{30}$ Just as the theme of making "sense of the war" would become prominent in the work of Virginia Woolf (Lewis 112).

31 The interwar period, in which politics and economics — as well as aesthetics — were profoundly interconnected, was a "pivotal moment". Keynes wrote an extremely influential and widely read work of political economics, the Economic Consequences of the Peace, which was published in 1919 and effectively predicted the Second World War. In it, we can point to a very specific moment of disillusionment for Keynes.
} 
after the first World War was "the mechanism by which it reduced the amount of purchasingpower in circulation, so that debts created during or shortly after the war, when the pound sterling was plentiful and had declined in its power to purchase goods, had to be repaid at a time when its power to purchase had increased considerably [benefiting bankers]." Pound wanted an easy answer, and bankers were an obvious target (Stock 187-8). His vehement attacks on usury would also feed into his "theories" on "the decline of the modern age, which he later blamed largely on Jewish financiers" (Lewis 122). Pound's (somewhat simplistic) reading of current economics and political affairs led him, unfortunately, to a familiar trope, one seeped in antiSemitism.

Pound idolized the Fascist Italian dictator Benito Mussolini in a "cult of the great leader" that was rooted, it has been argued, in a conflated and misplaced hope "for a return to the close relation between art and power, between artists and patrons," that he had "found in the 'vortices' of the Italian Renaissance" (Dasenbrock 233). Canto XLV can be read as a warning of the effects of a capitalist economy based on mediation, but also as a piece of Fascist propaganda. The vague pastoral imagery and largely Italian cultural references ("Pietro Lombardo / came not by usura / Duccio came not by usura / nor Pier della Francesca; Zuan Bellin' not by usura / nor was 'La Calunnia' painted. / Came not by usura Angelico; came not Ambrogio Praedis") evoke an idyllic view of (some unspecified past) Italian society. ${ }^{32}$ Pound did not see the form of government as

\footnotetext{
${ }^{32}$ This reaching to the past is also reflective of Pound's attempt to place his "ideal" (or "idyllic") economic system on some sort of moral footing, which recalls the medieval principle of "just price." This is ostensibly also a symptom of the reaction to the anxieties of modernity, the aftermath of the war, and the unraveling of society and previously held norms.
} 
important, as long it prevented war and kept the poisonous effects of greed at bay; as he stated in the postscript of the $A B C$ of Economics, "An economic system in which it is more profitable to make guns to blow men to pieces than to grow grain or make useful machinery, is an outrage" (125).

Where Pound saw the prevention of usury as a key means through which injustice could be averted and an ideal and egalitarian society promoted, Keynes's focal point was the prevention of unemployment — and authoritarianism. In Pound's holistic and simplified conception of a just and "good" economic system, the parts of society function as a whole; this view is in conflict with an individualistic capitalist society. Keynes, however, inaugurated the tradition of arguing that "economic prosperity was the only secure guarantee of liberal politics" (Skidelsky 364). For him, personal freedom and liberty were to be maintained at all costs, and greed — which he recognized as a potentially pernicious force — needed to be channeled through capitalist outlets to prevent wars and maintain peace. In his mature and complete economic theory, the final policy goal would be to boost demand and encourage spending, so that more people are hired, i.e. unemployment goes down. Keynes was deeply committed to preserving personal freedom, but he had been so disenchanted by the First World War that he felt that unemployment, a "disease", had to be removed - through non-authoritarian means. As he stated towards the end of The General Theory, "The authoritarian state systems of to-day seem to solve the problem of unemployment at the expense of efficiency and of freedom. It is certain that the world will not much longer tolerate the unemployment which, apart from brief intervals of excitement, is associated — and, in my opinion, inevitably associated — with present-day capitalistic individualism. But it may be possible by a right analysis of the problem to cure the disease whilst preserving efficiency and freedom" (240). At the end of Chapter I of Keynes's $A$ 
Tract on Monetary Reform, he stated that "it is worse, in an impoverished world, to provoke unemployment than to disappoint the rentier" (40). Although their visions of the ideal economic system and their "final" goals - the reduction of unemployment and the creation of an egalitarian society in which labor was exactly and fairly paid, respectively — were quite different, both Pound and Keynes were driven by some of the same underlying motivations, namely a deep aversion to injustice and war.

Keynes's General Theory contains a passage, a line of which ("It is better that a man should tyrannise over his bank balance than over his fellow-citizens") is especially well-known, that goes into more depth on his views on greed, government, and the need to channel the motive of "money-making" to neutralize human tendencies towards war:

Moreover, dangerous human proclivities can be canalised into comparatively harmless channels by the existence of opportunities for money-making and private wealth, which, if they cannot be satisfied in this way, may find their outlet in cruelty, the reckless pursuit of personal power and authority, and other forms of self-aggrandisement. It is better that a man should tyrannise over his bank balance than over his fellow-citizens [...] Though in the ideal commonwealth men may have been taught or inspired or bred to take no interest in the stakes, it may still be wise and prudent statesmanship to allow the game to be played, subject to rules and limitations, so long as the average man, or even a significant section of the community, is in fact strongly addicted to the money-making passion. (236)

We note the reference to an "ideal" commonwealth, some version of which both Keynes and Pound had in mind. While Keynes believed that it was, on a certain level, necessary for an "average man" in a real society to be "strongly addicted to the money-making passion," in 
Pound's ideal commonwealth or republic, as described in the $A B C$ of Economics, the gambler's "instinct" would not be "romanticized" and would "likely not survive" (107). Keynes was taken, correctly or not, as a direct embodiment, and an important proponent, of everything that was wrong with the liberal and artificial capitalist economic system Pound despised, a system that was very much based on this "instinct".

In the small economy portrayed in "With Usura," usury prevents not only the various factors of economic production ("stonecutter is kept from his tone"; "weaver is kept from his loom"; "usura is a "murrain"; it "blunteth the needle in the maid's hand" and "stoppeth the spinner's cunning"), but simultaneously the artistic modes - which are critical to civilization itself ("Came not by usura Angelico; came not Ambrogio Praedis"). The $A B C$ of Economics has a very short chapter that equivocates the "intelligence" of Mussolini. ${ }^{33}$ "The Duce's [Mussolini's] aphorisms and perceptions can be studied apart from his means of getting them into action" (119). Pound's view on gold further points to his inclination towards strong-men leaders: "Gold could serve as measure even with the new and fancy brands of economics, so long as the issuance of money (needed for exchange) isn't ham-strung or exploited by people who happen to have the gold at a given moment" (127). Having one powerful person in charge of a society would solve the issues of mediation and the corruption of gold as "just another" form of artificial money. "The best system of government, economically speaking, is that which best balances the four elements listed above, be it republic, monarchy, or soviet or dictatorship" ( $A B$ Cof Economics 118).

In the $A B C$ of Economics, Pound describes "an expression" of an economic principle

\footnotetext{
${ }^{33}$ Chapter III, "Dictatorship as Sign of Intelligence".
} 
"simple enough to be understood by almost anyone, save possibly Maynard Keynes or some paid mouthpiece of British Liberalism" (122). He consistently attacked Keynes personally, often in caustic terms. There is even a direct, and highly dismissive, reference to the economist in Canto XXII, as "Mr. Bukos" (Terrell 90). After the first World War, inflation was notably high; Pound wrote in the Canto about the "helplessness of orthodox economists in dealing with" these macroeconomic problems (Redman 45-6):

And C.H. said to the renowned Mr. Bukos:

"What is the cause of the H.C.L?" and Mr. Bukos,

The economist consulted of nations, said:

\section{"Lack of labour."}

And there were two millions of men out of work.

And C.H. shut up, he said

He would save his breath to cool his own porridge,

But I didn't, and I went on plaguing Mr. Bukos

Who said finally: "I am an orthodox

Economist." 34

Pound's interest in Keynes was, further, longstanding, and outlived Keynes himself, who died prematurely of a heart attack in 1946 at the age of 62. In 1959, when Pound was 74, a Virginia newspaper published his editorial piece, "Keynes Brainwashed Electorate with Economic Hogwash," that "in typical Pound style" was a "scathing swipe at the English economist, occasioned by an article that Pound had not bothered to read" (Schneider).

It is worth mentioning, as a brief aside, that Pound's own economic situation, apart from his economics, and apart from his attitude towards wealth and greed as abstract concepts, can

\footnotetext{
${ }^{34}$ As quoted in Redman (46). "C.H." is Major Douglas. The "economist consulted of nations" is a likely reference to Keynes's role at the Paris Peace Conference.
} 
help explain the level of personal antipathy he had towards Keynes. It also helps explain the incongruence that exists in his poetic work, as well as in his writings on economics. His $A B C$ of Economics dealt with contemporary issues, it but has a persistent attachment to idyllic ideas. Pound spoke of economic hardships with resentment and, at moments, acerbic bitterness, especially when talking about the negative impact they had on the production of the arts. In the $A$ $B C$ of Reading, he disparages the "carious and wholly filthy system of economics" as being the cause of the "aspiring poet in his garret" who never goes to a concert "either from lack of curiosity, or because he can't afford to buy concert tickets" (156). For Pound, economic issues were the "chief cause of false writing," as "many writers need or want money," writers who "could be cured by an application of banknotes" (193-4). The issue of "idleness", in the context of production in the arts, is another interesting focal point on which to compare Keynes and Pound, although I will not treat it in any depth here. ${ }^{35}$ Pound's family history can be seen as one of the factors that can be used to "deconstruct" and explain his "obsession" with money; these factors include "his grandfather's silver mines and lost fortunes, his father's post at the US Mint and, of course, his polysemic surname" (Wilson 111) ${ }^{36}$. Wilson, however, sees it as more likely that Pound's obsession with money had to do with his own precarious financial situation: his reliance on "allowances from his family and subsidies from his wife" and the fact that he made

\footnotetext{
${ }^{35}$ The issue of the "value" of the arts is a complex issue. Economic necessity can be prohibitive to poetic creativity, and the "idleness" of artists is a persistent stereotype. Correctly or not, idleness and unemployment are often linked, something that is recognized in the $A B C$ of Economics.

${ }^{36}$ Ezra Pound's father, Homer, was an assayer at the United States Mint in Philadelphia. The verb "assay," according to Merriam-Webster, means "to analyze (something, such as an ore) for one or more specific components." It also has the meaning "to judge the worth of."
} 
very little from his writing, but was also "generous by nature" (111), especially towards struggling young writers. Keynes, on the other hand, was quite wealthy - he was born into a relatively well-off Cambridge family, and he managed to amass a great fortune over his lifetime by skillfully applying his knowledge of investing and markets. It is not, therefore, completely extravagant to suggest that part of Pound's antipathy towards Keynes could be related to their differences in not only public reception, but also financial status, where idealism fell short of more pragmatic concerns.

While bad writing was, for Pound, often caused by economic hardship, good writing was not only necessary for society, but at the very foundation of civilization itself, as he explained in the $A B C$ of Reading: "The man of understanding can no more sit quiet and resigned while his country lets its literature decay, and let good writing meet with contempt, than a good doctor could sit quiet and contented while some ignorant child was infecting itself with tuberculosis under the impression that it was merely eating jam tarts" (33). He wrote, furthermore, that the "dirtiest book" in English was a quite astute manual telling people how to earn money by writing" (89). 


\section{Conclusions}

Both of the economic texts cited in this thesis, Pound's A B C of Economics and Keynes's A Tract on Monetary Reform, merit more in-depth study. The case study, although short, illustrates the extent to which certain poems in The Cantos are framed in terms of, and infused with, economic issues. On specific topics, Keynes and Pound are useful critical counterpoints, but they can also be compared on a systemic theoretical level. Although Keynes was a generally more methodical thinker than Pound, the entirety of his thought can be considered as a philosophical whole. He was greatly influenced by the work of the Cambridge philosopher G.E. Moore and Moore's conception of the "good," which had a strong impact on members of Bloomsbury. Keynes had a "conception of the good life" that "influenced both the way he lived his own life, and his public aims" (Skidelsky 289). Pound's thought has, in a similar way, been considered holistically.

As Jean-Michel Rabaté pointed out in his Language, Sexuality, and Ideology in Ezra Pound's Cantos, while Pound's “'obsession' with money and usury has been well documented, and is generally dismissed as the main root of all his 'aberrations,", at the same time, his "system of thought" was complex and should not be oversimplified, as it simultaneously "reveals an attempt to inscribe the moving and complex signature of his name in the world of history and art" (183). There was a profound moral underpinning to the economic and political thought of both Keynes and Pound; Pound's understanding of economics and political economy, however, was also partially responsible for his misguided sympathy for fascism.

In Canto XLV, "With Usura," we see an example of these ideas, through their expression in Pound's presentation of a small economic society or state. Although economics and literature are frequently seen, especially today, as belonging in separate realms, they are both concerned 
with issues of representation and fundamental questions related to the nature of things; "Nature" itself, in the sense of the natural world and its outputs; and, perhaps most vexingly, human nature. The gold standard debate of the early twentieth century was a tangible example of the intersection of these issues. Pound's economics and his poetic thought were, in the context of the political and economic turmoil of these years, reactive and paradoxical. They must be understood together.

\section{Word count: 11,086}


Peeters 43

Appendix 
I. Canto XLV, With Usura (1936)

With Usura

With usura hath no man a house of good stone

each block cut smooth and well fitting

that design might cover their face,

with usura

hath no man a painted paradise on his church wall

harpes et luz

or where virgin receiveth message

and halo projects from incision,

with usura

seeth no man Gonzaga his heirs and his concubines

no picture is made to endure nor to live with

but it is made to sell and sell quickly

with usura, sin against nature,

is thy bread ever more of stale rags

is thy bread dry as paper,

with no mountain wheat, no strong flour

with usura the line grows thick

with usura is no clear demarcation

and no man can find site for his dwelling.

Stonecutter is kept from his tone

weaver is kept from his loom

WITH USURA

wool comes not to market

sheep bringeth no gain with usura

Usura is a murrain, usura

blunteth the needle in the maid's hand

and stoppeth the spinner's cunning. Pietro Lombardo

came not by usura

Duccio came not by usura

nor Pier della Francesca; Zuan Bellin' not by usura

nor was 'La Calunnia' painted.

Came not by usura Angelico; came not Ambrogio Praedis,

Came no church of cut stone signed: Adamo me fecit.

Not by usura St. Trophime

Not by usura Saint Hilaire,

Usura rusteth the chisel

It rusteth the craft and the craftsman 
It gnaweth the thread in the loom

None learneth to weave gold in her pattern;

Azure hath a canker by usura; cramoisi is unbroidered

Emerald findeth no Memling

Usura slayeth the child in the womb

It stayeth the young man's courting

It hath brought palsey to bed, lyeth

between the young bride and her bridegroom

CONTRA NATURAM

They have brought whores for Eleusis

Corpses are set to banquet

at behest of usura.

N.B. Usury: A charge for the use of purchasing power, levied without regard to production; often without regard to the possibilities of production. (Hence the failure of the Medici bank.) 


\section{Excerpt from Keynes' 1923 A Tract on Monetary Reform (Chapter IV, “Alternative} Aims")

\section{The Restoration of a Gold Standard}

Our conclusions up to this point are, therefore, that when stability of the internal price level and stability of the external exchanges are incompatible, 164 the former is generally preferable; and that on occasions when the dilemma is acute, the preservation of the former at the expense of the latter is, fortunately perhaps, the line of least resistance.

The restoration of the gold standard (whether at the pre-war parity or at some other rate) certainly will not give us complete stability of internal prices and can only give us complete stability of the external exchanges if all other countries also restore the gold standard. The advisability of restoring it depends, therefore, on whether, on the whole, it will give us the best working compromise obtainable between the two ideals.

The advocates of gold, as against a more scientific standard, base their cause on the double contention, that in practice gold has provided and will provide a reasonably stable standard of value, and that in practice, since governing authorities lack wisdom as often as not, a managed currency will, sooner or later, come to grief. Conservatism and skepticism join armsas they often do. Perhaps superstition comes in too; for gold still enjoys the prestige of its smell and colour.

The considerable success with which gold maintained its stability of value in the changing world of the nineteenth century was certainly remarkable. I have applauded it in the first chapter. After the discoveries of Australia and California it began to depreciate dangerously, and before the exploitation 165 of South Africa it began to appreciate dangerously. Yet in each case it righted itself and retained its reputation. 
But the conditions of the future are not those of the past. We have no sufficient ground for expecting the continuance of the special conditions which preserved a sort of balance before the war. For what are the underlying explanations of the good behaviour of gold during the nineteenth century?

In the first place, it happened that process in the discovery of gold mines roughly kept pace with progress in other directions - a correspondence which was not altogether a matter of chance, because the progress of that period, since it was characterised by the gradual opening up and exploitation of the world's surface, not unnaturally brought to light pari passu the remoter deposits of gold. But this stage of history is now almost at an end. A quarter of a century has passed by since the discovery of an important deposit. Material progress is more dependent now on the growth of scientific and technical knowledge, of which the application to gold-mining may be intermittent. Years may elapse without great improvement in the methods of extracting gold; and then the genius of a chemist may realise past dreams and forgotten hoaxes, transmuting base into precious like Subtle, or extracting gold from sea-water as in the Bubble. Gold is liable to be either too dear or too cheap. In either case, it is too much to expect 166 that a succession of accidents will keep the metal steady.

But there was another type of influence which used to aid stability. The value of gold has not depended on the policy or the decisions of a single body of men; and a sufficient proportion of the supply has been able to find its way, without any flooding of the market, into the Arts or into the hoards of Asia for its marginal value to be governed by a steady psychological estimation of the metal in relation to other things. This is what is meant by saying that gold has "intrinsic value" and is free from the dangers of a "managed" currency. The independent variety of the influences determining the value of gold has been in itself a steadying influence. The 
arbitrary and variable character of the proportion of gold reserves to liabilities maintained by many of the note-issuing banks of the world, so far from introducing an incalculable factor, was an element of stability. For when gold was relatively abundant and flowed towards them, it was absorbed by their allowing their ratio of gold reserves to rise slightly; and when it was relatively scarce, the fact that they had no intention of ever utilising their gold reserves for any practical purpose, permitted most of them to view with equanimity a moderate weakening of their proportion. A great part of the flow of South African gold between the end of the Boer War and 1914 was able to find its way into the central gold reserves 167 of European and other countries with the minimum effect on prices.

But the war has effected a great change. Gold itself has become a "managed" currency. The West, as well as the East, has learnt to hoard gold; but the motives of the United States are not those of India. Now that most countries have abandoned the gold standard, the supply of the metal would, if the chief user of it restricted its holding to its real needs, prove largely redundant. The United States has not been able to let gold fall to its "natural" value, because it could not face the resulting deprecation of its standard. It has been driven, therefore, to the costly policy of burying in the vaults of Washington what the miners of the Rand have laboriously brought to the surface. Consequently gold now stands at an "artificial" value, the future course of which almost entirely depends on the policy of the Federal Reserve Board of the United States. The value of gold is no longer the resultant of the chance gifts of Nature and the judgment of numerous authorities and individuals acting independently. Even if other countries gradually return to a gold basis, the position will not be greatly changed. The tendency to employ some variant of the gold-exchange standard and the probably permanent disappearance of gold from the pockets of the people are likely to mean that the strictly necessary gold reserves of the Central Banks of the 
gold-standard countries will fall 168 considerably short of the available supplies. The actual value of gold will depend, therefore, on the policy of three or four of the most powerful Central Banks, whether they act independently or in unison. If, on the other hand, pre-war conventions about the use of gold in reserves and in circulation were to be restored - which is, in my opinion, the must less probable alternative - there might be, as Professor Cassel has predicted, a serious shortage of gold leading to a progressive appreciation in its value.

Nor must we neglect the possibility of a partial demonetisation of gold by the United States through a closing of its mints to further receipts of gold. The present policy of the United States in accepting unlimited imports of gold can be justified, perhaps, as a temporary measure, intended to preserve tradition and to strengthen confidence through a transitional period. But, looked at as a permanent arrangement, it could hardly be judged otherwise than as a foolish expense. If the Federal Reserve Board intends to maintain the value of the dollar at a level which is irrespective of the inflow or outflow of gold, what object is there in continuing to accept at the mints gold which is not wanted, yet costs a heavy price? If the United States mints were to be closed to gold, everything, except the actual price of the metal, could continue precisely as before.

Confidence in the future stability of the value of gold depends therefore on the United States being foolish enough to go on accepting gold which it does not want, and wise enough, having accepted it, to maintain it at a fixed value. This double event might be realised through the collaboration of a public understanding nothing with a Federal Reserve Board understanding everything. But the position is precarious; and not very attractive to any country which is still in a position to choose what its future standard is to be. 
This discussion of the prospects of the stability of gold has partly answered by anticipation the second principal argument in favour of the restoration of an unqualified gold standard, namely that this is the only way of avoiding the dangers of a "managed" currency.

It is natural, after what we have experienced, that prudent people should desiderate a standard of value which is independent of Finance Ministers and State Banks. The present state of affairs has allowed to the ignorance and frivolity of statesmen an ample opportunity of bringing about ruinous consequences in the economic field. It is felt that the general level of economic and financial education amongst statesmen and bankers is hardly such as to render innovations feasible or safe; that, in fact, a chief object of stabilising the exchanges is to strap down Ministers of Finance.

These are reasonable grounds of hesitation. But the experience on which they are based is by no means 170 fair to the capacities of statesmen and bankers. The non-metallic standards, of which we have experience, have been anything rather than scientific experiments coolly carried out. They have been a last resort, involuntarily adopted, as a result of war or inflationary taxation, when the State finances were already broken or the situation out of hand. Naturally in these circumstances such practices have been the accompaniment and the prelude of disaster. But we cannot argue from this to what can be achieved in normal times. I do not see that the regulation of the standard of value is essentially more difficult than many other objects of less social necessity which we attain successfully.

If, indeed, a providence watched over gold, or if Nature had provided us with a stable standard ready-made, I would not, in an attempt after some slight improvement, hand over the management to the possible weakness or ignorance of Boards and Governments. But this is not the situation. We have no ready-made standard. Experience has shown that in emergencies 
Ministers of Finance cannot be strapped down. And — most important of all—in the modern world of paper currency and bank credit there is no escape from a "managed" currency, whether we wish it or not;--convertibility into gold will not alter the fact that the value of gold itself depends on the policy of the Central Banks.

It is worth while to pause a moment over the last 171 sentence. It differs significantly from the doctrine of gold reserves which we learnt and taught before the war. We used to assume that no Central Bank would be so extravagant as to keep more gold than it required or so imprudent as to keep less. From time to time gold would flow out into the circulation or for export abroad; experience showed that the quantity required on these occasions bore some rough proportion to the Central Bank's liabilities; a decidedly higher proportion than this would be fixed on to provide for contingencies and to inspire confidence; and the creation of credit would be regulated largely by reference to the maintenance of this proportion. The Bank of England, for example, would allow itself to be swayed by the tides of gold, permitting the inflowing and outflowing streams to produce their "natural" consequences unchecked by any ideas as to preventing the effect on prices. Already before the war, the system was becoming precarious by reason of its artificiality. The "proportion" was by the lapse of time losing its relation to the facts and had become largely conventional. Some other figure, greater or less, would have done just as well. ${ }^{37}$ The War broke down the convention; for the withdrawal of gold from actual circulation destroyed one of the elements of reality lying behind the convention, and the suspension of convertibility 172 destroyed the other. It would have been absurd to regulate the bank rate by reference to a "proportion" which had lost all its significance; and in the course of the past ten years a new policy has been evolved. The bank rate is now employed, however incompletely and

\footnotetext{
${ }^{37}$ Vide, for what I wrote about this in 1914, The Economic Journal, xxiv. P. 621.
} 
experimentally, to regulate the expansion and deflation of credit in the interests of business stability and the steadiness of prices. In so far as it is employed to procure stability of the dollar exchange, where this is inconsistent with stability of internal prices, we have a relic of pre-war policy and a compromise between discrepant aims.

Those who advocate the return to a gold standard do not always appreciate along what different lines our actual practice has been drifting. If we restore the gold standard, are we to return also to the pre-war conceptions of bank-rate, allowing the tides of gold to play what tricks they like with the internal price-level, and abandoning the attempt to moderate the disastrous influence of the credit-cycle on the stability of prices and employment? Or are we to continue and develop the experimental innovations of our present policy, ignoring the "bank ratio" and, if necessary, allowing unmoved a piling up of gold reserves far beyond our requirements or their depletion far below them?

In truth, the gold standard is already a barbarous relic. All of us, from the Governor of the Bank of England downwards, are now primarily interested in 173 preserving the stability of business, prices, and employment, and are not likely, when the choice is forced on us, deliberately to sacrifice these to the out-worn dogma, which had its value once, of $£ 3: 17: 101 / 2$ per ounce. Advocates of the ancient standard do not observe how remote it now is from the spirit and the requirements of the age. A regulated non-metallic standard has slipped in unnoticed. It exists. While the economists dozed, the academic dream of a hundred years, doffing its cap and gown, clad in paper rags, has crept into the real world by means of the bad fairies-always so much more potent than the good-the wicked Ministers of Finance.

For these reasons enlightened advocates of the restoration of gold, such as Mr. Hawtrey, do not welcome it as the return of a "natural" currency, and intend, quite decidedly, that it shall 
be a "managed" one. They allow gold back only as a constitutional monarch, shorn of his ancient despotic powers and compelled to accept the advice of a Parliament of Banks. The adoption of the ideas present in the minds of those who drafted the Genoa Resolutions on Currency is an essential condition of Mr. Hawtrey's adherence to gold. He contemplates "the practice of continuous co-operation among central banks of issue" (Res. 3), and an international convention, based on a gold exchange standard, and designed "with a view to preventing undue fluctuations 174 in the purchasing power of gold" (Res. 11) ${ }^{38}$ But he is not in favour of resuming the gold standard irrespective of "whether the difficulties in regard to the future purchasing power of gold have been provided against or not." "It is not easy," he admits, "to promote international action, and should it fail, the wisest course for the time being might be to concentrate on the stabilisation of sterling in terms of commodities, rather than tie the pound to a metal, the vagaries of which cannot be foreseen." ${ }^{39}$

It is natural to ask, in face of advocacy of this kind, why it is necessary to drag in gold at all. Mr. Hawtrey lays no stress on the obvious support for his compromise, namely the force of sentiment and tradition, and the preference of Englishmen for shearing a monarch of his powers rather than of his head. But he adduces three other reasons: (1) that gold is required as a liquid reserve for the settlement of international balances of indebtedness; (2) that it enables an experiment to be made without cutting adrift from the old system; and (3) that the vested interests of gold produces must be considered. These objects, however, are so largely attained by my own suggestions in the following chapter, that I need not dwell on them here.

\footnotetext{
${ }^{38}$ Monetary Reconstruction, p. 132

${ }^{39}$ Loc. Cit, p. 22
} 
On the other hand, I see grave objections to reinstating gold in the pious hope that international co-operation will keep it in order. With the existing 175 distribution of the world's gold, the reinstatement of the gold standard means, inevitably, that we surrender the regulation of our price level and the handling of the credit cycle to the Federal Reserve Board of the United States. Even if the most intimate and cordial co-operation is established between the Board and the Bank of England, the preponderance of power will still belong to the former. The Board will be in a position to disregard the Bank. But if the Bank disregard the Board, it will render itself liable to be flooded with, or depleted of, gold, as the case may be. Moreover, we can be confident beforehand that there will be much suspicion amongst Americans (for that is their disposition) of any supposed attempt on the part of the Bank of England to dictate their policy or to influence American discount rates in the interests of Great Britain. We must also be prepared to incur our share of the vain expense of bottling up the world's redundant gold.

It would be rash in present circumstances to surrender our freedom of action to the Federal Reserve Board of the United States. We do not yet possess sufficient experience of its capacity to act in times of stress with courage and independence. The Federal Reserve Board is striving to free itself from the pressure of sectional interests; but we are not yet certain that it will wholly succeed. It is still liable to be overwhelmed by the impetuosity of a cheap money campaign. A suspicion of British influence 176 would, so far from strengthening the Board, greatly weaken its resistance to popular clamour. Nor is it certain, quite apart from weakness or mistakes, that the simultaneous application of the same policy will always be in the interests of both countries. The development of the credit cycle and the state of business may sometimes be widely different on the two sides of the Atlantic. 
Therefore, since I regard the stability of prices, credit, and employment as of paramount importance, and since I feel no confidence that an old-fashioned gold standard will even give us the modicum of stability that it used to give, I reject the policy of restoring the gold standard on pre-war lines. At the same time I doubt the wisdom of attempting a "managed" gold standard jointly with the United States, on the lines recommended by Mr. Hawtrey, because it retains too many of the disadvantages of the old system without its advantages, and because it would make us too dependent on the policy and on the wishes of the Federal Reserve Board. 
III. Graph: Value of Gold in the Aftermath of the 2008 Financial Crisis

\section{Up and down}

Gold, \$ per oz

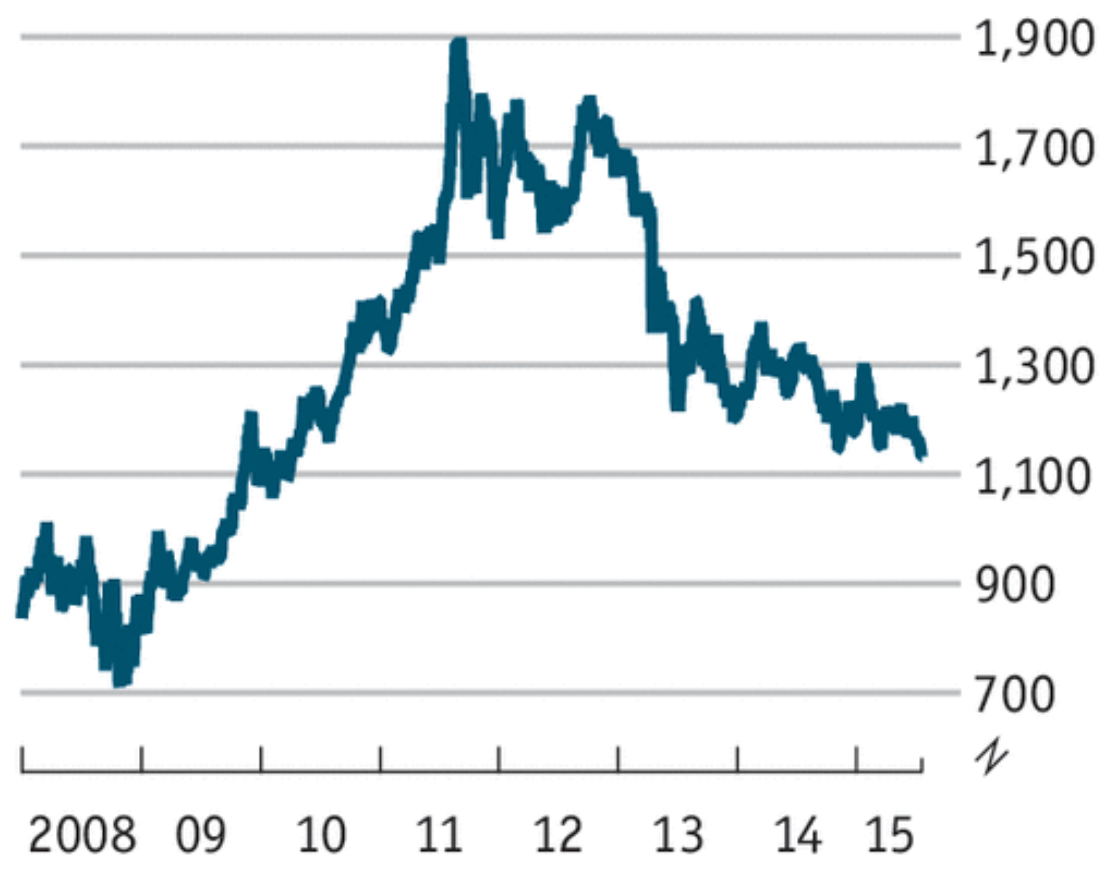

Source: Thomson Reuters

\section{Economist.com}


IV. Portraits

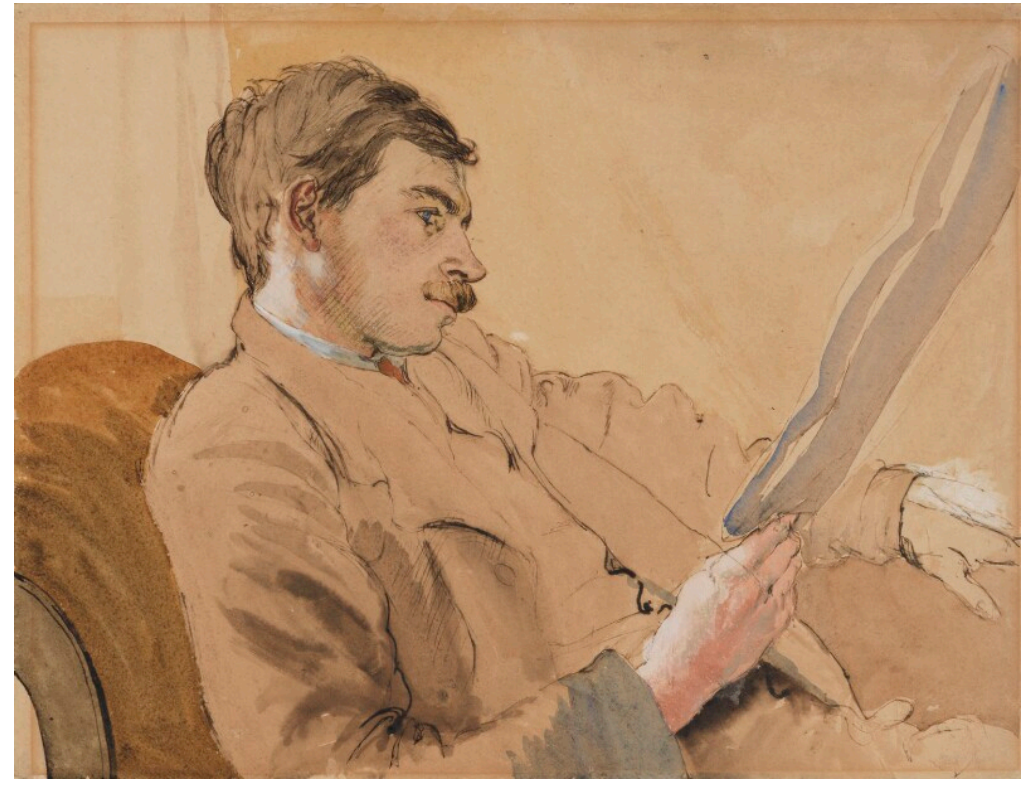

John Maynard Keynes, by Gwendolen Raverat (1908)

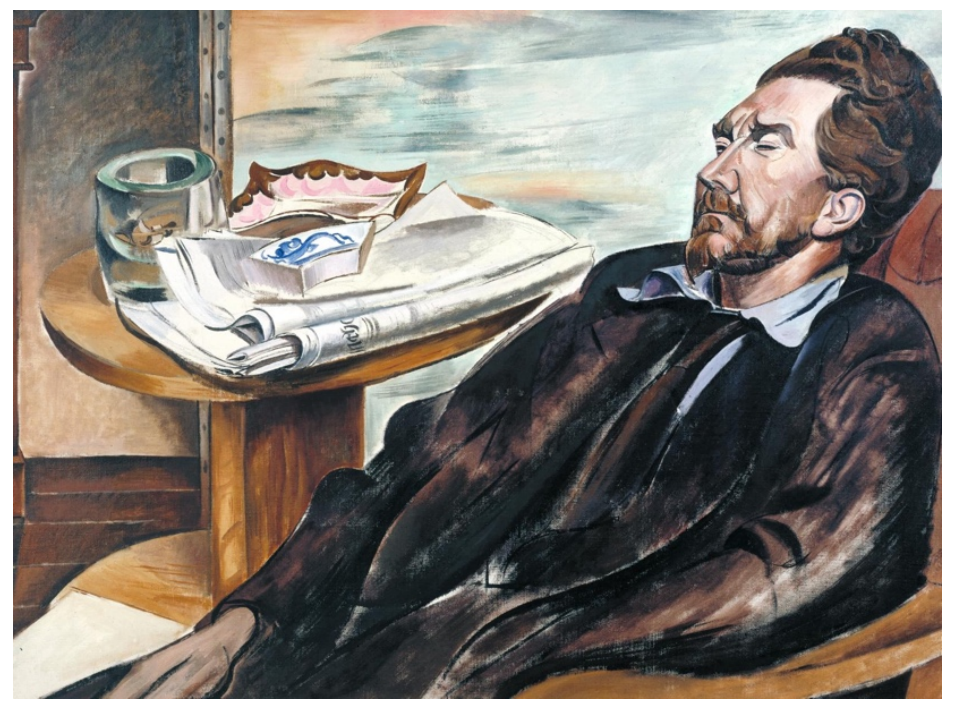

Ezra Pound, by Wyndham Lewis (1938) 


\section{Works Cited}

“A Cambridge Secret Revealed: The Apostles.” King's College Cambridge, 2011, www.kings.cam.ac.uk/archive-centre/archive-month/january-2011.html. Accessed 1 June 2017.

“A Man for All Seasons.” The Economist, 2015, www.economist.com/news/books-andarts/21650521-there-was-far-more-keynes-being-economist-man-all-seasons. Accessed 1 June 2017.

“A Solitary Volcano.” The Economist, 2007, www.economist.com/node/9982906. Accessed 1 June 2017.

Andolfatto, David. "The Gold Standard and Inflation.” The St. Louis Fed, 2014, www.stlouisfed.org/on-the-economy/2014/august/the-gold-standard-and-priceinflation. Accessed 1 June 2017.

“Assayer.” Merriam-Webster, www.merriam-webster.com/dictionary/assayer. Accessed 1 June 2017.

"Benefits of Price Stability.” European Central Bank, 2017, www.ecb.europa.eu/mopo/intro/benefits/html/index.en.html. Accessed 1 December 2017.

Bordo, Michael. "Gold Standard." The Concise Encyclopedia of Economics, www.econlib.org/library/Enc/GoldStandard.html. Accessed 1 June 2017.

“Central Bank.” Financial Times Lexicon, http://lexicon.ft.com/Term?term=central-bank. Accessed 1 December 2017.

“Contra Naturam”. Merriam-Webster, www.merriam-webster.com/dictionary/assayer. Accessed 1 December 2017. 
Dasenbrock, Reed Way. "Pound and the Visual Arts." The Cambridge Companion to Ezra Pound, edited by Ira B. Nadel, 1999, pp. 224-35.

Davenport-Hines, Ricard. Universal Man: The Seven Lives of John Maynard Keynes. HarperCollins UK, 2015.

Debreu, Gerard. "The Mathematization of Economic Theory." The American Economic Review, vol. 81 , no. 1, 1991, pp. 1-7.

de Man, Paul. "Semiotics and Rhetoric." Diacritics, vol. 3, no. 3, 1973, pp. 27-33.

Dilligan, Robert J. et al. A Concordance to Ezra Pound's Cantos. Garland Publishing, Inc. 1981. Eichengreen, Barry and Peter Temin. "The Gold Standard and the Great Depression." Contemporary European History, vol. 9, no. 2, 2000, pp. 183-207.

Emre, Merv. "The General Theory." The Modernism Lab at Yale University, modernism.research.yale.edu/wiki/index.php/John_Maynard_Keynes_and_Artisti Conventions. Accessed 15 October 2016.

"Exchange Rate." Financial Times Lexicon, lexicon.ft.com/Term?term=exchange-rate. Accessed 1 December 2017.

"Ezra Pound." The Poetry Foundation, www.poetryfoundation.org/poets/ezra-pound. Accessed 1 June 2017.

"Gold Standard." Financial Times Lexicon, lexicon.ft.com/Term?term=Gold-Standard. Accessed 1 December 2017.

Heidegger, Martin. "Language." The Norton Anthology of Theory and Criticism. Eds. Leitch, Vincent B. et al. 2nd ed. Norton, 2010, pp. 985-97.

“Inflation." Financial Times Lexicon, lexicon.ft.com/Term?term=inflation. Accessed 1 December 2017. 
Keynes, John Maynard. “Economic Possibilities for Our Grandchildren.” Essays in Persuasion. Macmillan, 1931.

Keynes, John Maynard. The General Theory of Interest, Employment, and Money. Macmillan for the Royal Economic Society, 1971.

Keynes, John Maynard. Tract on Monetary Reform. Macmillan, 1923.

Lewis, Pericles. The Cambridge Introduction to Modernism. Cambridge University Press, 2007.

Lewis, Wyndham. Ezra Pound. 1938, Oil paint on canvas. Tate, London

"Lord Keynes Dies of Heart Attack." On This Day (New York Times), www.nytimes.com/learning/general/onthisday/bday/0605.html?mcubz=1. Accessed 1 June 2017.

Marsh, Alec. Ezra Pound. Reaktion Books, 2011.

Menand, Louis. “The Pound Error.” The New Yorker, 2008.

"Modernism." The Princeton Encyclopedia of Poetry and Poetics. Eds. Greene, Roland et al., 4th ed. Princeton University Press, 2012, pp. 892-4.

Morrison, Paul. The Poetics of Fascism: Ezra Pound, T.S. Eliot, Paul de Man. Oxford University Press, 1996.

Moss, David A. A Concise Guide to Macroeconomics: What Managers, Executives, and Students Need to Know. 2nd ed. Harvard Business Review Press, 2014.

"Paul de Man." The Norton Anthology of Theory and Criticism. Eds. Leitch, Vincent B. et al., 2nd ed. Norton, 2010, pp. 1361-4.

Pound, Ezra. A B C of Economics. Faber and Faber, 1933.

Pound, Ezra. A B C of Reading. Faber and Faber, 1934.

Pound, Ezra. “Canto LLIV." Cantos of Ezra Pound. New Directions, 1996. 
Pound, Ezra. “Canto XLV.” Cantos of Ezra Pound. New Directions, 1996.

Pound, Ezra. "Lustra.” Poetry, Nov. 1913, pp. 57-8.

Pound, Ezra. "Volitionist Economics.” Ezra Pound and 'Globe’ Magazine: The Complete Correspondence, Eds. Michael T. Davis and Cameron McWhirter, Bloomsbury Publishing, 2015, pp. 144-5.

Rabaté, Jean-Michel. Language, Sexuality, and Ideology in Ezra Pound's Cantos. SUNY Press, 1986.

Raverat, Gwendolen. John Maynard Keynes. 1908, pen and ink and watercolor. National Portrait Gallery, London.

Redman, Tim. Ezra Pound and Italian Fascism. Cambridge University Press, 1991.

Saussure, Ferdinand de. "Nature of the Linguistic Sign." The Norton Anthology of Theory and Criticism. Eds. Leitch, Vincent B. et al. 2nd ed. Norton, 2010, pp. 852-5.

“Secundum Naturam.” Merriam-Webster, www.merriam-webster.com/dictionary/assayer. Accessed 1 December 2017.

Sieburth, Richard. "In Pound We Trust: The Economy of Poetry/The Poetry of Economics." Critical Inquiry, vol. 14, no. 1, 1987, pp. 142-72.

Schneider, John. "Ezra Pound: Foreign Correspondent." Virginia Quarterly Review, vol. 84, no. 2, 2008 .

Skidelsky, Robert. John Maynard Keynes 1883-1946: Economist, Philosopher, Statesman. Macmillan, 2003.

Stock, Noel. Poet in Exile: Ezra Pound. Manchester University Press, 1964.

Terrell, Carroll F. A Companion to the Cantos of Ezra Pound. University of California Press, 1980. 
“TIMELINE - Gold's history as a currency standard.” Reuters, uk.reuters.com/article/idINIndia-52748720101108. Accessed 1 December 2017.

“Trump Favors Returning to The Gold Standard, Few Economists Agree." Morning Edition. NPR, Washington, DC, 16 Jun. 2016.

Vilches, Elvira. New World Gold: Cultural Anxiety and Monetary Disorder in Early Modern Spain. University of Chicago Press, 2010.

"Why the Gold Price is Falling." The Economist Explains, www.economist.com/blogs/economist-explains/2015/07/economist-explains-17. Accessed 1 December 2017.

Wicke, Jennifer. “'Mrs. Dalloway' Goes to Market: Woolf, Keynes, and Modern Markets.” NOVEL: A Forum on Fiction, vol. 28, no. 1, 1994, pp. 5-23.

Wilson, Peter. A Preface to Ezra Pound. Addison Wesley Longman Limited, 1997. 